BBA 75 I 57

\title{
PROTEIN PATTERNS OF RED CELL MEMBRANES FROM DIFFERENT MAMMALIAN SPECIES
}

R. F. A. ZWAAL AND L. L. M. VAN DEENEN

Department of Biochemistry, Laboratory of Organic Chemistry, Croesestraat 79, Utrecht (The Netherlands)

(Received March 5th, I968)

SUMMARY

I. Erythrocyte membrane proteins of human, rat, rabbit, pig, ox and sheep have been solubilized by $n$-butanol fractionation of aqueous ghost suspensions.

2. The solubility of the different protein solutions and their lipid composition has been studied.

3. Sedimentation in an analytical ultracentrifuge and disc electrophoresis in polyacrylamide demonstrated that the protein composition of the erythrocyte membranes from the mammalian species is markedly different.

Considerable differences have been established in the lipid composition of erythrocyte membranes between different mammalian species (for a review see ref. I). With a view to the associations between lipids and proteins in these membranes, the question arises whether differences also exist in the make-up of the protein moieties among these membranes.

$\mathrm{MADDY}^{2,3}$ solubilized $90-95 \%$ of the proteins from ghosts of ox erythrocytes by treatment with $n$-butanol. This procedure has also been applied to human erythrocyte ghosts $^{4,5}$, giving a recovery of $83 \%$ of membrane protein in the butanol-saturated water phase. Other investigators, however, reported a very low yield of protein from human erythrocyte ghosts ${ }^{\mathbf{6}, 7}$. In the present study, human, rat, rabbit, pig, ox and sheep erythrocyte ghosts were subjected to the butanol fractionation procedure. In all cases, $85-90 \%$ of the proteins from the ghosts were found to be solubilized in the water layer remaining after butanol extraction, while $90-95 \%$ of the lipids were recovered in the butanol phase. About Io-I $5 \%$ of the proteins and less than $5 \%$ of the lipids were lost in the interfacial film.

\section{The solubility of the proteins}

Sometimes a precipitate was formed during dialysis of the butanol-saturated protein solution. Similar observations were made by REGA et al. ${ }^{4}$ who replaced the dialysis by an evaporation procedure. The formation of a precipitate has to be attributed to a rather low $\mathrm{pH}$ of the distilled water causing isoelectric precipitation of the proteins, because, on raising the $\mathrm{pH}$ of the distilled water above 5.5 with buffer, this precipitate dissolved. MADDY ${ }^{3}$ had already found that the structural proteins of 
ox erythrocytes are precipitated between $\mathrm{pH} 3.7$ and 4.8. It appeared that the proteins obtained from human, rat, pig, ox and sheep erythrocyte ghosts were also insoluble in this $\mathrm{pH}$ region. However, the proteins of rabbit erythrocyte ghosts remained soluble between $\mathrm{pH} 3.7$ and 4.8 , although the lucidity of the solution was diminished. Since isoelectric precipitation was used for concentrating the proteins, no further experiments have been done with the proteins from rabbit erythrocytes.

The solubility of the proteins appeared to withstand heating for $\mathrm{I} \mathrm{h}$ at $100^{\circ}$ but the proteins became insoluble immediately after freezing of the solutions. The latter behaviour was also observed by REGA et al.4. In all cases the proteins were found to be precipitated between $32.5-40 \%\left(\mathrm{NH}_{4}\right)_{2} \mathrm{SO}_{4}$ saturation and between $45-50 \%$ of acetone.

\section{Lipid composition of the aqueous phase}

MADDY $^{3}$ and REGA et al. ${ }^{4}$ had already reported that the aqueous phase contained a small amount of lipid. After lyophilisation of the aqueous phase, extraction with chloroform-methanol demonstrated that $0.4-0.8 \%$ of the cholesterol and $3-5 \%$ of the phospholipids from the ghost were present in this fraction. No obvious differences were noted among the erythrocytes from different species. The phospholipid composition of the aqueous phase, resulting after solubilisation of the proteins from the erythrocytes of the various mammals, is given in Table I. In all cases, a relatively large amount of phosphatidyl serine was found to be present, this being in agreement with the observations of REGA et al. ${ }^{4}$ on human erythrocytes. It is not clear whether this effect is caused by a stronger binding of the serine phosphoglyceride to protein or is due to a lower solubility in butanol. After repeating the butanol extraction of the protein solution four times, no more lipid was detectable in the aqueous phase but a considerable loss of protein occurred at the interface.

TABLE I

PHOSPHOLIPID COMPOSITION OF THE AQUEOUS PHASES OBTAINED AFTER BUTANOL EXTRACTION OF ERYTHROCYTE GHOST SUSPENSIONS

Phosphatidic acid, phosphatidyl inositol and lysolecithin are not analysed.

\begin{tabular}{lrrrrrrr}
\hline & Human & Rat & Rabbit & Pig & Ox & Sheep \\
\hline & & & & & & \\
Phosphatidyl ethanolamine & 4.4 & 10.6 & 10.5 & 2.4 & 8.0 & 9.4 \\
Lecithin & 7.0 & 13.3 & 9.7 & 4.5 & 8.5 & 13.9 \\
Sphingomyelin & I 5.5 & 37.2 & 38.8 & 28.1 & 33.4 & 25.0 \\
Phosphatidyl serine & 73.1 & 39.0 & $4 I .1$ & 65.1 & 50.1 & 5 I. 8 \\
\hline
\end{tabular}

\section{Analytical ultracentrifugation}

The material solubilized from human erythrocyte ghosts separated into two fractions (Fig. I) with sedimentation coefficients of 7 and $23 \mathrm{~S}$ and two shoulders (about 14 and $32 \mathrm{~S}$ ). Rat erythrocyte revealed a minor peak (5 S) and a major fraction (I2 S). The aqueous phase obtained from pig erythrocytes gave one broad peak ( $18 \mathrm{~S}$ ). The protein fraction from sheep erythrocytes revealed two peaks ( $9 \mathrm{~S}$ and Io S) and a shoulder ( $15.5 \mathrm{~S}$ ). The proteins solubilized from ox erythrocytes gave, as already found by MADDY ${ }^{3}$, two peaks (8 and II S), although the shapes and sedimentation 
coefficients are somewhat different. Most of the peaks were found to broaden considerably during the run, indicating that these fractions are heterogeneous.

\section{Disc electrophoresis}

The results of the electrophoresis experiments on the protein fractions solubilized according to the procedure of MADDY are reproduced in Fig. 2. It is clear that the electrophoretic patterns of the proteins differ significantly among the erythrocytes of the mammals studied. A complex of bands has already been detected by disc electrophoresis $^{\mathbf{1 3}, 14}$ and starch-gel electrophoresis in human erythrocyte ghosts, after solubilization by different methods. The pattern of proteins solubilized from rat erythrocyte ghosts is equally complex. The electrophoretic separation of the proteins
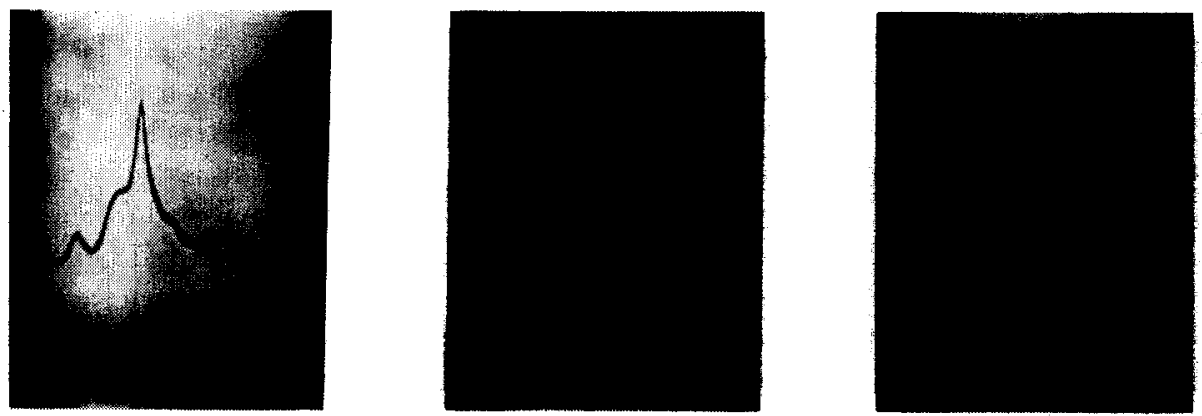

Fig. I. Sedimentation patterns of the aqueous phases after butanol extraction in Spinco Model I:. Solvent: phosphate buffer $(\mathrm{pH} 7.0, I$, o.I). A, human; 56 Ioo rev./min. B, rat (upper pattern) and pig (lower pattern); $59780 \mathrm{rev} . / \mathrm{min}$. C, Sheep (upper pattern) and ox (lower pattern); 59780 rev./min.

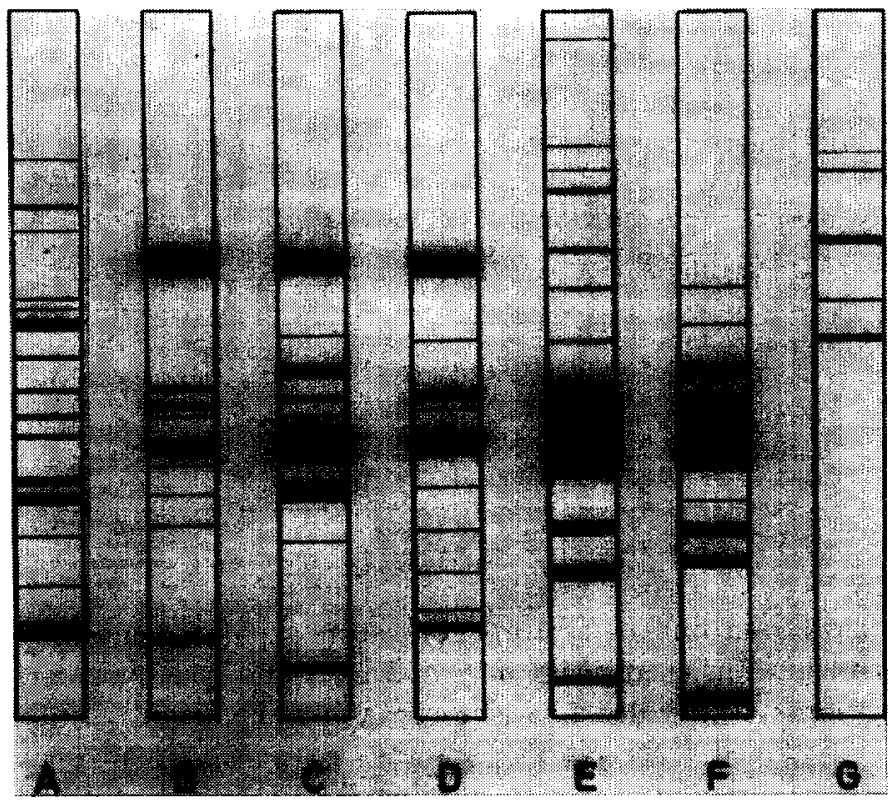

Fig. 2. Disc-electrophoretic patterns of the protein solutions after butanol fractionation (details described in the experimental section). A, rat; B, pig; C, ox; D, sheep; E, human; F, Fraction I (human); G, Fraction II (human). (For Fraction I and II cf. Fig. 3.) 
from ghosts of pig, ox and sheep gives a somewhat simpler picture. The slowestmoving band appears to have about the same mobility for these three animal species. Although some other bands with similar mobility may be observed in the electrophoretograms of two or more species, the over-all patterns of the various species are markedly different. In order to determine whether the complexity of the electrophoretic patterns was due to artifacts, the proteins obtained from human erythrocytes were separated into two fractions by centrifugation in a sucrose gradient (Fig. 3).

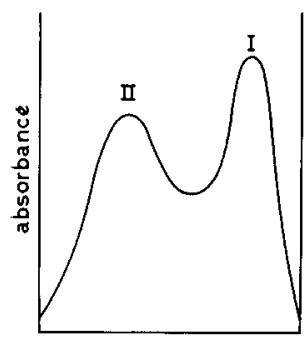

fraction number

Fig. 3. Separation of the human structural proteins into two fractions by density-gradient centrifugation for $3 \mathrm{~h}$ in a sucrose gradient (13-5.5\%) in a Spinco Model L2-65, SW 29 rotor at 375 oo rev. $/ \mathrm{min} .0 .5 \mathrm{ml}$ of protein solution in Tris- $\mathrm{HCl}(\mathrm{pH} 7.2, I, 0.05)$ containing $4-5 \mathrm{mg}$ protein was applied to the gradient and II-drop fractions were collected after puncture of the bottom of the tube. Alsorbances were measured at $280 \mathrm{~m} \mu$.

The two fractions were collected, dialysed and concentrated in $3 \%$ acetic acid- $6 \mathrm{M}$ urea prior to the electrophoretic procedure. Fig. 2 ( $F$ and $G$ ) shows the electrophoretic patterns obtained from the two peaks. It is apparent that previous fractionation by sucrose-gradient centrifugation does not significantly alter the number of protein bands or their mobilities.

It is not yet possible to correlate the variations observed in the protein patterns of the erythrocyte membranes with any of the differences found in the lipid composition. The results, however, endorse the view that there is a non-uniformity in the chemical make-up of the lipoproteins constituting the erythrocyte envelope of different mammalian species.

EXPERIMENTAL

\section{Preparation of the erythrocyte ghosts}

Erythrocyte ghosts were prepared by a slight modification of the method of Dodge, Mitchell and Hanahan ${ }^{8}$. Fresh blood from humans, rats, rabbits, pigs, oxen, and sheep was collected into citric acid-citrate-glucose $(22 \mathrm{vol}$. per Ioo vol. blood) and the serum and buffy coat were removed by washing three times with isotonic phosphate buffer (3IO mosM ( $\mathrm{pH}$ 7.4) o.I mM EDTA). The packed cells were haemolysed in 6 vol. of hypotonic phosphate buffer ( $20 \operatorname{mosM}(\mathrm{pH} 7.4)$ o.I mM EDTA) for $\mathrm{I}$ h. The membranes were collected by centrifugation of the haemolysate at $30000 \times g$ for $20 \mathrm{~min}$ and washed repeatedly with the hypotonic phosphate buffer until haemoglobin-free ghosts were obtained. The ghost suspensions were frozen overnight at $-25^{\circ}$, thawed the next day and washed three times with distilled water. All washings were carried out at $2^{\circ}$. 
During the preparation of the ghosts no differences were noticed between those of humans and of the different animals. An exception has to be made for rat erythrocyte ghosts, which contained some heavy red material after centrifugation of the haemolysate. This was removed by carefully pouring the ghost suspension on top of the heavy precipitate into another centrifugation tube.

\section{Fractionation of the ghosts}

The ghost suspensions were fractionated with $n$-butanol according to the method described by MADDY ${ }^{2,3}$. The aqueous ghost suspensions were mixed with equal volumes of butanol at $0^{\circ}$ for $25 \mathrm{~min}$. After centrifugation at $30000 \times g$ for I5 min the mixtures were separated by a thin, insoluble interfacial film into an upper butanol layer containing the majority of lipids and a water layer mainly containing proteins. The aqueous phase was sucked out into a cold hypodermic syringe and dialysed overnight against distilled water at 4 .

\section{Concentration of the protein solutions}

After dialysis, the proteins were precipitated near their isoelectric point at $\mathrm{pH} 4.5$ by addition of $0.0 \mathrm{I} \mathrm{M} \mathrm{HCl}$ and collected by centrifugation at Iroo $\times g$ for $4 \mathrm{~min}$. The supernatant was removed and the resulting pad was solubilized in a few $\mathrm{ml}$ of phosphate buffer $(\mathrm{pH} 7.0, I$, o.I) for experiments with the analytical ultracentrifuge; for disc electrophoresis in polyacrylamide the pad was solubilized in $3 \%$ acetic acid $-6 \mathrm{M}$ urea. In this way, protein solutions with a concentration of up to $20 \mathrm{mg} / \mathrm{ml}$ could be obtained.

\section{Analytical methods}

Protein concentrations were measured according to the method of LowRY et al. ${ }^{9}$, using bovine albumin as a standard. Lipid content was determined after three-fold extraction of lyophilized proteins with chloroform-methanol $(2: \mathrm{I}, \mathrm{v} / \mathrm{v})$. Phospholipids were determined as phosphorus after destruction with $70 \% \quad \mathrm{HClO}_{4}$ at $180^{\circ}$ by a method of FISKE-SUBBARow ${ }^{\mathbf{1 0}}$. Cholesterol was analysed according to the procedure of WEBSTER ${ }^{11}$.

\section{Electrophoretic procedure}

Electrophoresis was carried out in the Shandon disc electrophoresis apparatus (Shandon Scientific Company, Ltd., London) using the standard 7.5\% polyacrylamide separating gel and the $2.5 \%$ polyacrylamide large-pore gel, both in the presence of $6 \mathrm{M}$ urea, with the glycine-acetic acid buffer prepared according to the Shandon formulations derived from ORNSTEIN AND DAvis ${ }^{12}$. The $\mathrm{pH}$ values were determined by a dual electrode and were found to be 3.5, 5.8, and 4.I for separating gel, large-pore gel and buffer, respectively. Protein concentrations were adjusted so that each sample $(50 \mu 1)$ loaded on top of the large-pore gel contained about $200-300 \mu \mathrm{g}$ protein. Electrophoresis was performed at $5 \mathrm{~mA}$ per column for $4 \mathrm{~h}$ at room temperature. The gels were extruded from the columns and fixed and stained in $\mathrm{I} \%$ amido black in $7 \%$ acetic acid, followed by electrolytic destaining. 


\section{ACKNOWLEDGEMENTS}

The present investigations have been carried out under the auspices of The Netherlands Foundation for Chemical Research (S.O.N.) and with financial aid from the Netherlands Organization for the Advancement of Pure Research (Z.W.O.).

The authors are indebted to Drs. J. A. L. I. Walters from the University of Nijmegen for carrying out the experiments with the analytical ultracentrifuge.

\section{REFERENCES}

I L. L. M. Van Deenen and J. De Gier, in The Red Blood Cell, Academic Press, New York, I964, Chapter VII, p. 243.

2 A. H. MADDy, Biochim. Biophys. Acta, 88 (1964) 448.

3 A. H. MAdDy, Biochim. Biophys. Acta, I I 7 (I966) 193.

4 A. F. Rega, R. I. Weed, C. F. Reed, G. G. Berg and A. Rothstein, Biochim. Biophys. Acta, I 47 (I967) 297.

5 A. F. Rega, R. I. Weed and A. Rothstein, Federation Proc., 25 (I966) 290.

6 M. J. Poulik and P. K. LaUf, Natuve, 208 (I965) 874 .

7 S. BaKerman and G. Wasemiller, Biochemistry, 6 (I967) 1100.

8 J. T. Dodge, C. J. Mitchell and D. J. Hanahan, Arch. Biochem. Biophys., ioo (I963) II9.

9 O. H. Lowry, N. J. Rosebrough, A. L. Farr and R. J. Randall, J. Biol. Chem., I93 (I95I) 265.

io C. J. F. Böttcher, C. M. Van Gent and C. Pries, Anal. Chim. Acta, 24 (I96i) 203.

I I D. Webster, Clin. Chim. Acta, 7 (I962) 277.

I2 L. Ornstein and B. J. Davis, Ann. N.Y. Acad. Sci., I 2 I (1964) 305.

I 3 E. A. Azen, S. OrR ANd O. Smithies, J. Lab. Clin. Med., 65 (1965) 440.

I4 L. J. Schneiderman, Biochem. Biophys. Res. Commun., 20 (I965) 763. 